\title{
New Approach to Drug Delivery in Ophthalmological Practice: Development of Composite Ophthalmological Solution for Drug Loading of Soft Contact Lenses
}

\author{
Denis K. Naplekov' ${ }^{1}$ Elena T. Zhilyakova ${ }^{1}$, Anastasiya Yu. Malyutina ${ }^{1 *}$, Aleksander V. Bondarev', \\ Natalia B. Demina², Oleg O. Novikov³, Rimma A. Abramovich ${ }^{3}$
}

1 - Federal State Autonomous Educational Institution of Higher Education «Belgorod State University», 85, Pobedy str., Belgorod, 308015, Russia

2 - I. M. Sechenov First MSMU of the Ministry of Health of the Russian Federation (Sechenov University), 8/2, Trubetskaya str., Moscow, 119991, Russia

3 - Peoples Friendship University of Russia (RUDN University), 6, Mikluho-Maklaya str., Moscow, 117198, Russia

*Corresponding author: Anastasiya Yu. Malyutina. E-mail: malyutina_a@bsu.edu.ru

ORCID: Denis K. Naplekov - https://orcid.org/0000-0003-3753-4922; Elena T. Zhilyakova - https://orcid.org/0000-0002-8685-1601;

Anastasiya Yu. Malyutina - https://orcid.org/0000-0001-6170-2151; Aleksander V. Bondarev - https://orcid.org/0000-0002-5250-0731;

Natalia B. Demina - https://orcid.org/0000-0003-4307-8791; Oleg O. Novikov - https://orcid.org/0000-0002-7038-9803; Rimma A. Abramovich - https://orcid.org/0000-0003-1784-881X.

Received: 02.07.2020. Revised: 19.10 .2020 . Published: 24.11 .2020

\begin{abstract}
Introduction. This article provides a tentative justification of use of soft contact lenses as a carrier of ophthalmological solutions to eye tissues. Aim. The aim of the research is to develop the composition of the ophthalmic transport system for the treatment of glaucoma. Also, the proposed manufacturing algorithms were proposed for drug loading ophthalmological solutions.

Materials and methods. Preparation of sodium hyaluronate solution was carried out based on the methodology described in EP 7.0 [01/2011:1472] (Sodium hyaluronate).

Results and discussion. The conducted investigation with the purpose to justify a concentration of sodium hyaluronate helped to determine its concentration that gives the viscosity level as close to the upper limit stated in Russian Pharmacopoeia as possible. Buffer solution was chosen with criteria to use as less components in ophthalmological solution as possible. Also, it was found out that the more components are added to the viscous solution, the more viscosity level is decreased. Thus, initial viscosity of solution containing sodium hyaluronate was $149.59 \mathrm{~mm}^{2} / \mathrm{s}$, and after addition of active pharmaceutical substance it dropped down to $88.49 \mathrm{~mm}^{2} / \mathrm{s}$ and $81.36 \mathrm{~mm}^{2} / \mathrm{s}$ for model solution number 1 and 2 , respectively. After addition of citric acid and disodium hydrophosphate, the viscosity of model solution was found to be $78.11 \mathrm{~mm}^{2} / \mathrm{s}$ and $75.28 \mathrm{~mm}^{2} / \mathrm{s}$ for model solution number 1 and 2, respectively.

Conclusion. As a result of the studies, two alternative model compositions of an ophthalmic solution for the saturation of soft contact lenses for the treatment of glaucoma were proposed. The choice of active pharmaceutical substances, and excipients has been justified. Technological procedure of preparation of model solution was described and explained, where the most attention was paid on dissolving of sodium hyaluronate in purified water.
\end{abstract}

Keywords: soft contact lenses, mucoadhesive polymers, drug delivery, pharmaceutical technology.

Conflict of interest: no conflict of interest.

Contribution of the authors. Elena T. Zhilyakova and Denis K. Naplekov developed the approach to study the properties of soft contact lenses as the drug carriers. The proposed experimental strategy was approved by Elena T. Zhilyakova, Oleg O. Novikov, Natalia B. Demina and Rimma A. Abramovich. The measurements of viscosity of sodium hyaluronate solution were conducted by Denis K. Naplekov. Selection of active ingridients and excipient substances of the solution for drug loading of soft contact lenses was done by Aleksander V. Bondarev and Denis K. Naplekov. Quantitative assessment of intake and release processes of soft contact lenses was conducted by Denis K. Naplekov, Anastasiya Yu. Malyutina and Aleksander V. Bondarev via gravimetric and UV-spectrophotometry methods. Data processing and review of the results were done by Oleg O. Novikov, Anastasiya Yu. Malyutina and Elena T. Zhilyakova. The conclusion on the acquired experimental results were approved by Elena T. Zhilyakova, Oleg O. Novikov, Natalia B. Demina and Rimma A. Abramovich. All authors equally contributed to writing the current manuscript and approval of its text.

For citation: Naplekov D. K., Zhilyakova E. T., Malyutina A. Yu., Bondarev A. V., Demina N. B., Novikov O. O., Abramovich R. A. New approach to drug delivery in ophthalmological practice: development of composite ophthalmological solution for drug loading of soft contact lenses. Razrabotka $i$ registratsiya lekarstvennykh sredstv = Drug development \& registration. 2020;9(4):15-20. (In Russ.). https://doi.org/10.33380/2305-2066-2020-9-4-59-64

\section{Новый подход к доставке лекарственных средств в офтальмологической практике: разработка композитного офтальмологического раствора для лекарственной нагрузки мягких контактных линз}

\section{Д. К. Наплеков', Е. Т. Жилякова', А. Ю. Малютина', А. В. Бондарев', Н. Б. Демина², О. О. Новиков ${ }^{3}$, Р. А. Абрамович ${ }^{3}$}

1 - ФГАОУ ВО «Белгородский государственный национальный исследовательский университет», 308015, Россия, г. Белгород, ул. Победы, д. 85 2 - ФГАОУ ВО Первый МГМУ им. И. М. Сеченова Минздрава России (Сеченовский университет), 119991, Россия, г. Москва, ул. Трубецкая, д. 8, стр. 2 3 - ФГАОУ ВО «Российский университет дружбы народов» (Российский университет дружбы народов, РУДН), 117198, Россия, г. Москва, ул. Миклухо-Маклая, д. 6 *Контактное лицо: Малютина Анастасия Юрьевна. E-mail: malyutina_a@bsu.edu.ru 
ORCID: Д. К. Наплеков - https://orcid.org/0000-0003-3753-4922; Е. Т. Жилякова - https://orcid.org/0000-0002-8685-1601; A. Ю. Малютина - https://orcid.org/0000-0001-6170-2151; А. В. Бондарев - https://orcid org/0000-0002-5250-0731: Н. Б. Демина - https://orcid org/0000-0003-4307-8791; О. О. Новиков - https://orcid org/0000-0002-7038-9803,

Р. А. Абрамович - https://orcid.org/0000-0003-1784-881X.

Статья поступила: 02.07.2020. Статья принята в печать: 19.10.2020. Статья опубликована: 24.11 .2020

\section{Резюме}

Введение. В статье представлены данные по предварительному обоснованию применения мягких контактных линз в качестве носителя офтальмологических растворов и их доставки к тканям глаза.

Цель. Цель исследования - разработка состава офтальмологической транспортной системы для лечения глаукомы. Также предложены алгоритмы изготовления лекарственных препаратов для загрузки офтальмологических растворов.

Материалы и методы. Приготовление раствора гиалуроната натрия. проводили по методике, описанной в Европейской Фармакопее 7.0 [01/2011: 1472] (гиалуронат натрия).

Результаты и обсуждение. Проведенное исследование с целью обоснования концентрации гиалуроната натрия позволило определить его концентрацию, дающую уровень вязкости максимально приближенный к верхнему пределу, установленному в Российской фармакопее. Буферный раствор был выбран с учетом критериев использования как можно меньшего количества компонентов в офтальмологическом растворе. Также установлено, что чем больше компонентов добавляется в вязкий раствор, тем больше снижается уровень вязкости. Таким образом, начальная вязкость раствора, содержащего гиалуронат натрия, составила 149,59 мм²/с, а после добавления активного фармацевтического вещества она снизилась до 88,49 мм²/с и 81,36 мм²/с для модельного раствора № 1 и 2 соответственно. После добавления лимонной кислоты и динатриевого гидрофосфата вязкость модельного раствора составила 78,11 мм²/с и 75,28 мм²/с для модельного раствора № 1 и 2 соответственно.

Заключение. В результате проведенных исследований были предложены две альтернативные модельные композиции офтальмологического раствора для насыщения мягких контактных линз для лечения глаукомы. Обоснован выбор активных фармацевтических субстанций и вспомогательных веществ. Описана и объяснена технологическая процедура приготовления модельного раствора, где наибольшее внимание уделялось растворению гиалуроната натрия в очищенной воде.

Ключевые слова: мягкие контактные линзы, мукоадгезивные полимеры, доставка лекарственных средств, фармацевтическая технология. Конфликт интересов: конфликта интересов нет.

Вклад авторов. Е. Т. Жилякова и Д. К. Наплеков разработали подход к изучению свойств мягких контактных линз как носителей лекарственных веществ. Согласование предложенной стратегии эксперимента было осуществлено Е. Т. Жиляковой, О. О. Новиковым, Н. Б. Деминой и Р. А. Абрамович. Измерение вязкости раствора натрия гиалуроната было осуществлено Д. К. Наплековым. Подбор активных и вспомогательных компонентов раствора для насыщения мягких контактных линз был выполнен А. В. Бондаревым и Д. К. Наплековым. Количественная оценка процессов насыщения и высвобождения мягких контактных линз гравиметрическим и УФ-спектрофотометрическим методами была проведена Д. К. Наплековым, А. Ю. Малютиной и А. В. Бондаревым. Обработку и обзор полученных результатов осуществляли О. О. Новиков, А. Ю. Малютина и Е. Т. Жилякова. Заключение о результатах эксперимента было согласовано с Е. Т. Жиляковой, О. О. Новиковым, Н. Б. Деминой и Р. А. Абрамович. Все авторы в одинаковой степени участвовали в написании и согласовании текста статьи.

Для цитирования: Наплеков Д. К., Жилякова Е. Т., Малютина А. Ю., Бондарев А. В., Демина Н. Б., Новиков О. О., Абрамович Р. А. Новый подход к доставке лекарственных средств в офтальмологической практике: разработка композитного офтальмологического раствора для лекарственной нагрузки мягких контактных линз. Разработка и регистрация лекарственных средств. 2020;9(4):15-20. https://doi. org/10.33380/2305-2066-2020-9-4-59-64

\section{INTRODUCTION}

Since the first mention of soft contact lenses $(\mathrm{SCL})$ in the context of prolonged delivery of active pharmaceutical substances (API) to the eye tissues, a number of methods have been developed to date that allow saturating the lens with pharmacologically active agents. Among the very first and simplest methods for saturating $\mathrm{SCL}$, one can distinguish such as soaking SCL in an ophthalmic solution immediately or several hours before use, instilling eye drops (ED) on the surface of contact lenses already worn on the eyes [1]. Currently known methods of achieving a prolonged effect utilizing $\mathrm{SCL}$, have not proved their significant advantage over the use of ED. This is primarily due to the fact that $S C L$ are different in structure, the features of which determine the volume of a contact lens reservoir capable of absorbing drug molecules [2]. However, along with the drawbacks of modern methods of saturating contact lenses, there is also an advantage - the ability for the patient to independently prepare their SCL for the drug delivery process. In this regard, the method of soaking contact lenses in an oph- thalmic solution does not lose its relevance, and the search for new approaches to its improvement is a promising direction in the development of ophthalmic therapeutic systems [3].

It is presumably possible to explain the low efficiency of SCL drug loading by soaking, root cause of which is a low viscosity of the ophthalmic solution, which probably leads to excessively fast leaching of the drug substance from the lens surface into the external environment. At earlier stages of this research work, it was found that prolonged saturation of $\mathrm{SCL}$ with an ophthalmic solution leads to irreversible binding of drug molecules to the surface of the carrier. The solution to this problem can be an increase in the viscosity of the ophthalmic solution for saturation by introducing mucoadhesive substances into the composition, which, by increasing the viscosity, can also increase the residence time of drugs on the surface of the SCL [4]. Currently, a wide range of mucoadhesive substances is known, which by their nature are hydrophilic polymers and are used in the manufacture of preparations of the "artificial tear» group. Such substances include synthetic derivatives of cellulose: methyl cellulose, 
hydroxypropyl methyl cellulose, sodium salt of carboxymethyl cellulose, hydroxypropyl cellulose, etc. In addition, other hydrophilic polymers are known that are used as ophthalmic dosage form prolongers, among which carbomer, polyvinyl alcohol, sodium hyaluronate [5].

For the development of ophthalmic therapeutic systems based on $\mathrm{SCL}$, it is desirable that, in addition to mucoadhesive properties, the hydrophilic polymer also has pronounced lubricating properties. According to literature data, such requirements are met by sodium hyaluronate [6].

Thus, by introducing mucoadhesive substances into the composition of the ophthalmic solution to saturate the $\mathrm{SCL}$, the saturation of the lenses is expected not primarily as a result of intermolecular interaction of the polymer surface and the drug, but as a result of adhesion (adhesion) of a viscous ophthalmic solution with the lens surface [7]. Upon completion of the saturation process, by the time of use, the patient will receive contact lenses uniformly coated with a thin drug layer [8].

In addition to simple methods of using $\mathrm{SCL}$ as a means of drug delivery, there is an extensive group of high-tech methods for introducing drug molecules directly into SCL itself, usually at the stage of polymerization of its material: introducing colloidal particles (liposomes, nano/microemulsions, nanosuspensions) [9]; the inclusion of ligands in hydrogels; inclusion of the drug itself (molecular imprinting) in the polymer's SCL structure [10]. A common drawback of modern methods of introducing into the lens of the drug is the lack of the ability for the patient to independently perform this operation. Among other negative aspects of high-tech methods for saturating SCL, labor intensity, time consuming and, as a result, the high cost of the final product are separately singled out [11].

Speaking about the development of the composition and technology of the ophthalmic therapeutic system, it is the ophthalmic solution that is meant to saturate $S C L$ as the most critical component of the system. It is assumed that the patient fills the SCL container with the drug solution and places the SCL there for a certain period. For some time, due to the high viscosity, the solution of active substances binds to the surface of the $\mathrm{SCL}$, which is then removed from the container and placed on the affected eye for wear during the day. Thus, the release of a viscous solution from the surface of the SCL and its distribution over the surface of the eye is initiated, from which the start of the absorption process and the emergence of a therapeutic effect are expected.

The purpose of this fragment of a large-scale study was to develop the composition of an ophthalmic solution for saturation of SCL.

\section{MATERIALS AND METHODS}

Preparation of sodium hyaluronate solution. The preparation of solutions was carried out based on the methodology described in EP 7.0 [01/2011:1472] (Sodium hyaluronate). Accurate samples of the substance were weighed on an electronic balance with an accuracy of $0.001 \mathrm{~g}$ in accordance with the planned concentration of the solution, $25 \mathrm{~mL}$ of water for injection was measured in each heat-resistant chemical beaker. Chemical glasses with water for injection were placed on the heating platform of a heated magnetic stirrer and the heating function was turned on. When the temperature of the water for injection reached $50{ }^{\circ} \mathrm{C}$, the heating function was turned off and stirring was turned on at low speed. Weighed portions of hyaluronic acid, corresponding to a certain concentration of the solution, were gradually introduced in small portions into a beaker. After the hyaluronic acid was added, stirring was continued for $30 \mathrm{~min}$. Next, the beakers with solutions were removed from the heating element of the magnetic stirrer, their contents were transferred to volumetric flasks, rinsing the bottom of the beaker with water for injection to avoid loss of hyaluronic acid concentration, after which the solution volume was adjusted to $100 \mathrm{~mL}$ with water for injection. The solution was considered correctly prepared if gel particles were not visually detected in the transmitted light in the solution $[12,13]$.

The calculation of the osmolarity of the studied solutions was carried out according to the formula 1.

$$
C_{o s m}=\sum \frac{m_{i} \cdot n_{i} \cdot 100}{M_{i}}
$$

where $C_{\text {osm }}$ - osmolarity of solution, $\mathrm{mOsm} / \mathrm{L} ; m_{i}$ - substance content in solution, $\mathrm{g} / \mathrm{L} ; n_{i}$ - total number of ions formed from a single molecule of a solute as a result of dissociation; $M_{i}-$ molar mass of the substance, $\mathrm{g} / \mathrm{mol}$.

\section{RESULTS AND DISCUSSION}

A study was conducted of model solutions of sodium hyaluronate of various concentrations in order to select the optimal viscosity of the solution to saturate $\mathrm{SCL}$ as part of an ophthalmic therapeutic system.

In General Pharmacopoeia Monograph 1.4.1.0003.15 "Ophthalmic dosage forms» the recommended viscosity for eye drops is from 5 to $15 \mathrm{~mm}^{2} / \mathrm{s}$. However, if it is necessary to ensure higher mucoadhesiveness of the ophthalmic solution, a viscosity of up to $150 \mathrm{~mm}^{2} / \mathrm{s}$ is justified. The higher the value of the viscosity of the solution for drug loading, the greater the specific work required for its separation with the surface of the $\mathrm{SCL}$. And this is important to ensure the prolonged action of the drug.

Based on the data presented above, it is rational to choose a hydrophilic polymer to increase the viscosity of an ophthalmic sodium hyaluronate solution. In addition, it is one of the most popular substances used in the manufacture of artificial tear preparations [14-16]. Therefore, the ophthalmological therapeutic system acquires an additional positive property to wetting the surface of the eye and, accordingly, reducing the likelihood of developing adverse events associated with wearing SCL. In this regard, model solutions of sodium hyaluronate were prepared in concentrations from $0.05 \%$ to $1.00 \%$ in increments of $0.05 \%$. 
Figure 1 shows the dynamics of changes in the viscosity of the solution with increasing concentration of sodium hyaluronate.

As can be seen from the data presented in figure 1, with an increase in the concentration of sodium hyaluronate, an increase in the viscosity of its solution was also observed. In order to meet the requirements of general pharmacopeia monograph ОФC.1.4.1.0003.15 and at the same time ensure the maximum possible degree of binding of the ophthalmic solution to the surface of the $\mathrm{SCL}$, a $0.5 \%$ sodium hyaluronate solution with a viscosity value of $149.59 \mathrm{~mm}^{2} / \mathrm{s}$ was chosen.

The following drug combinations in recommended doses were proposed as active substances in an ophthalmic solution for saturating SCL: brimonidine tartrate + pyridoxine hydrochloride and betacolol hydrochloride + pyridoxine hydrochloride. The use of both compositions suggests a decrease in intraocular pressure and a simultaneous regeneration of eye tissues.

The physicochemical properties of model solutions containing the active components were measured, including with the aim of choosing the amount of buffer. The results are presented in table 1.

As follows from the data presented in table 1, the viscosity of model solutions with active components is less than in placebo solutions of sodium hyaluronate. It amounted to $88.49 \mathrm{~mm}^{2} / \mathrm{s}$ and $81.36 \mathrm{~mm}^{2} / \mathrm{s}$ for model solution 1 and 2, respectively. Based on the obtained $\mathrm{pH}$ data, both model solutions are acidic mixtures with close $\mathrm{pH}$ values. In this regard, it was rational to introduce a buffer solution into the composition in order to maintain a $\mathrm{pH}$ level that is comfortable for the eye tissues. Considering the purpose and availability of the components, a phosphate buffer having the following composition was selected for the composition of the ophthalmic solution being developed: $82.4 \mathrm{~mL}$ of disodium hydrophos- phate solution $(71.5 \mathrm{~g} / \mathrm{L})$ and $17.6 \mathrm{~mL}$ of citric acid solution $(21 \mathrm{~g} / \mathrm{L})$. It was experimentally found that in order to achieve acceptable human eye $\mathrm{pH}$ values of model solutions with a volume of $100 \mathrm{ml}, 0.0085 \mathrm{~g}$ of citric acid and $0.0290 \mathrm{~g}$ of disodium hydrogen phosphate are required.

Table 1. Compositions and physicochemical parameters of model solutions

Таблица 1. Составы и физико-химические параметры модельных растворов

\begin{tabular}{|c|c|c|c|}
\hline \multirow{2}{*}{\multicolumn{2}{|c|}{ Composition of model solution }} & \multicolumn{2}{|c|}{$\begin{array}{c}\text { Physicochemical } \\
\text { parameters }\end{array}$} \\
\hline & & $\begin{array}{c}\text { Viscosity, } \\
\mathrm{Mm}^{2} / \mathrm{c} \\
\end{array}$ & $\mathbf{p H}$ \\
\hline \multicolumn{2}{|l|}{ Model solution 1} & \multirow{5}{*}{88.49} & \multirow{5}{*}{4.17} \\
\hline Brimonidine tartrate & $0.006 \mathrm{~g}$ & & \\
\hline Pyridoxine hydrochloride & $0.009 \mathrm{~g}$ & & \\
\hline Sodium hyaluronate & $0.015 \mathrm{~g}$ & & \\
\hline Water purified for injetions & up to $3 \mathrm{~mL}$ & & \\
\hline \multicolumn{2}{|l|}{ Model solution 2} & \multirow{5}{*}{81.36} & \multirow{5}{*}{4.82} \\
\hline Betaxolol hydrochloride & $0.017 \mathrm{~g}$ & & \\
\hline Pyridoxine hydrochloride & $0.009 \mathrm{~g}$ & & \\
\hline Sodium hyaluronate & $0.015 \mathrm{~g}$ & & \\
\hline Water purified for injetions & up to $3 \mathrm{~mL}$ & & \\
\hline
\end{tabular}

In its turn, the theoretical osmolarity of the developed compounds was calculated, taking into account the requirements of the general pharmacopoeia monograph OФC.1.2.1.0003.15 «Osmolarity», where solutions meeting the osmolarity range of $239-376 \mathrm{mOsm} / \mathrm{L}$ are considered isotonic.

The results of calculating the theoretical osmolarity of the proposed solutions are presented in table 2 .

From table 2 it follows that all formulations meet the recommended requirements for osmolarity, and the osmolarity of model solutions 1 and 2 varies slightly, is 304.03 and $366.42 \mathrm{mOsm} / \mathrm{L}$, respectively. The grea-

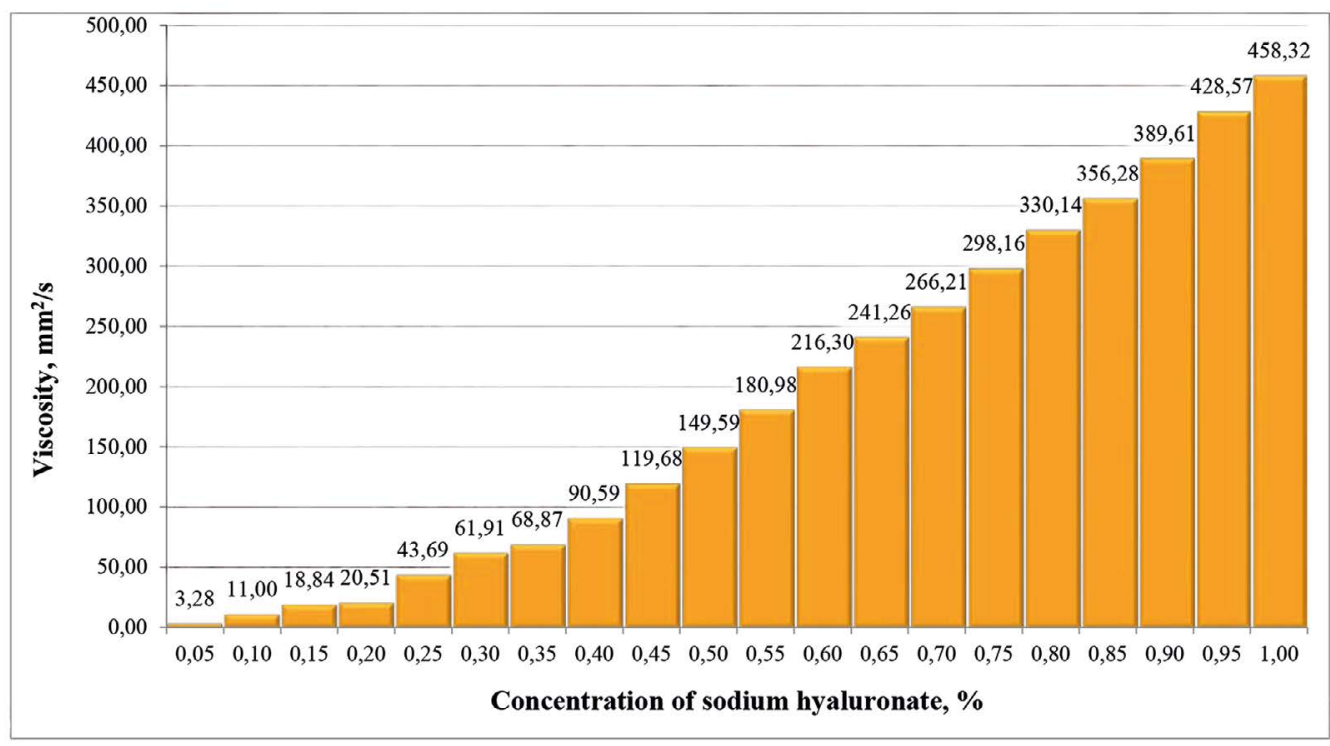

Figure 1. The dynamics of the viscosity of solutions with increasing concentration of sodium hyaluronate

Рисунок 1. Динамика вязкости растворов с увеличением концентрации гиалуроната натрия 
test influence on the osmolarity of the proposed model solutions is exerted by one of the components of the phosphate buffer, disodium hydrophosphate, whose osmolarity is $272.46 \mathrm{mOsm} / \mathrm{L}$.

Based on the theoretically calculated osmolarity values for all the proposed model solutions, the introduction of an additional amount of sodium chloride for the purpose of isotonization was not required.

Table 2. Theoretical osmolarity values of model solutions

Таблица 2. Теоретические значения осмолярности модельных растворов

\begin{tabular}{|c|l|c|c|}
\hline \multirow{2}{*}{ No } & \multirow{2}{*}{ Component } & \multicolumn{2}{|c|}{ Model solution } \\
\cline { 3 - 4 } & & № 1 & № 2 \\
\cline { 3 - 4 } & & Osmolarity, mOsm/L \\
\hline 1 & Brimonidine tartrate & 12.17 & - \\
\hline 2 & Betaxolol hydrochloride & - & 32.57 \\
\hline 3 & Pyridoxine hydrochloride & 29.17 & 29.17 \\
\hline 4 & Citric acid & 29.56 & 29.56 \\
\hline 5 & Disodium hydrophosphate & 272.46 & 272.46 \\
\hline 6 & Sodium hyaluronate & 0.67 & 0.67 \\
\hline 7 & $\begin{array}{l}\text { Summarized osmolarity, } \\
\text { mOsm/L }\end{array}$ & 344.03 & 364.42 \\
\hline
\end{tabular}

Table 3 presents the results of a study of the physicochemical properties of the proposed solutions.

Table 3. Physico-chemical properties of model solutions

Таблица 3. Физико-химические свойства модельных растворов

\begin{tabular}{|l|c|c|}
\hline \multirow{2}{*}{ Parameter } & \multicolumn{2}{|c|}{ Model solution } \\
\cline { 2 - 3 } & № 1 & № 2 \\
\hline Transparency and turbidity & Transparent & Transparent \\
\hline Color & Colorless liquid & Colorless liquid \\
\hline $\mathrm{pH}$ & 7.34 & 7.47 \\
\hline Viscosity, mm²/s & 78.11 & 75.28 \\
\hline $\begin{array}{l}\text { Theoretical osmolarity, } \\
\text { mOsm/L }\end{array}$ & 344.03 & 364.42 \\
\hline
\end{tabular}

From the data given in table 3, it follows that both model solutions according to physicochemical parameters meet the requirements of General Pharmacopoeia Article 1.4.1.0003.15 «Ophthalmic dosage forms». Thus, the compositions of the proposed model ophthalmic solutions are presented with the results of calculations of API and excipients in table 4.

In laboratory conditions, model solutions were prepared as follows.

Phosphate buffer solution: $50 \mathrm{~mL}$ of water for injection was measured into a $100 \mathrm{ml}$ beaker and the mixture was heated. Upon reaching a temperature of $30^{\circ} \mathrm{C}$ with constant stirring, the components of the borate buffer were added in the following sequence: citric acid $0.284 \mathrm{~g}$, disodium hydrophosphate $-0.967 \mathrm{~g}$. The next component was added after complete dissolution of the previous one.

Simultaneously, in another $100 \mathrm{~mL}$ beaker, a $30 \mathrm{~mL}$ sodium hyaluronate solution was prepared according to the procedure described above.
Table 4. The proposed compositions of the ophthalmic solutions for drug loading of SCL

Таблица 4. Предлагаемые композиции офтальмологических растворов для лекарственной нагрузки мягких контактных линз

\begin{tabular}{|l|c|}
\hline \multicolumn{2}{|c|}{ Composition per $100 \mathrm{~mL}$} \\
\hline \multicolumn{2}{|c|}{ Model solution 1 } \\
\hline Brimonidine tartrate & $0.2 \mathrm{~g}$ \\
\hline Pyridoxine hydrochloride & $0.3 \mathrm{~g}$ \\
\hline Citric acid & $0.284 \mathrm{~g}$ \\
\hline Disodium hydrophosphate & $0.967 \mathrm{~g}$ \\
\hline Sodium hyaluronate & $0.5 \mathrm{~g}$ \\
\hline Water purified for injetions & up to $100 \mathrm{~mL}$ \\
\hline \multicolumn{2}{|c|}{ Model solution 2 } \\
\hline Betaxolol hydrochloride & $0.56 \mathrm{~g}$ \\
\hline Pyridoxine hydrochloride & $0.3 \mathrm{~g}$ \\
\hline Citric acid & $0.284 \mathrm{~g}$ \\
\hline Disodium hydrophosphate & $0.967 \mathrm{~g}$ \\
\hline Sodium hyaluronate & $0.5 \mathrm{~g}$ \\
\hline Water purified for injetions & up to $100 \mathrm{~mL}$ \\
\hline
\end{tabular}

In $50 \mathrm{~mL}$ of a solution of phosphate buffer with constant stirring, the amounts of APIs presented in table 4 were added. The mixture was stirred until complete dissolution of the active substances, after which stirring was continued for 30 minutes.

To $30 \mathrm{~mL}$ of sodium hyaluronate solution was added $50 \mathrm{~mL}$ of a solution containing phosphate buffer, brimonidine tartrate and pyridoxine hydrochloride, after which stirring was carried out for another 10 minutes. The resulting solution from the beaker was transferred to a $100 \mathrm{~mL}$ volumetric flask, the volume was adjusted to the mark with water for injection, rinsing the bottom and walls of the beaker with the aim of transferring the full volume of the components included in the solution. The transparency of the solution, the absence of visible gel particles, $\mathrm{pH}$, and viscosity were controlled.

\section{CONCLUSTIONS}

As a result of the studies, two alternative model compositions of an ophthalmic solution for the saturation of $\mathrm{SCL}$ for the treatment of glaucoma were proposed. These developments are planned for further use in the process of creating an ophthalmic transport system. The choice of active pharmaceutical substances, and excipients has been justified. Technological procedure of preparation of model solution was described and explained, where the most attention was paid on dissolving of sodium hyaluronate in purified water. The conducted investigation with the purpose to justify a concentration of sodium hyaluronate helped to determine its concentration that gives the viscosity level as close to the upper limit stated in Russian Pharmacopoeia as possible. Buffer solution was chosen with criteria to use as less components in ophthalmological solution as possible. Also, it was found out that the more components are added to the viscous solution, the more viscosity level is decreased. Thus, initial viscosity of solution containing sodium hyaluronate 
was $149.59 \mathrm{~mm}^{2} / \mathrm{s}$, and after addition of active pharmaceutical substance it dropped down to $88.49 \mathrm{~mm}^{2} / \mathrm{s}$ and $81.36 \mathrm{~mm}^{2} / \mathrm{s}$ for model solution number 1 and 2, respectively. After addition of citric acid and disodium hydrophosphate, the viscosity of model solution was found to be $78.11 \mathrm{~mm}^{2} / \mathrm{s}$ and $75.28 \mathrm{~mm}^{2} / \mathrm{s}$ for model solution number 1 and 2, respectively. All studies were conducted in accordance with the regulations of State Pharmacopoeia of The Russian Federation, XIV edition.

The results were obtained under state grant No. 12.6429.2017/BCh «Complex research of plant-origin objects in the process of creating targeted dosage forms for proctology».

\section{REFERENCES}

1. Mei Y., Yangfan Y., Ming L., Chengtian Y., Chunshun Zh., Jiangang X. Kaili W., Minbin Y. Experimental studies on soft contact lenses for controlled ocular delivery of pirfinedone: in vitro and in vivo. Drug Delivery. 2016;23(9):3538-3543.

2. Hegde R. R., Verma A., Ghosh A. Microemulsion: New Insights into the Ocular Drug Delivery. ISRN Pharm. 2013;1:82-98.

3. Maulvi F. A., Lakdawala D. H., Shaikh A. A., Desai A. R., Choksi H. H., Vaidya R. J., Ranch K. M., Koli A. R., Vyas B. A., Shah D. O. In vitro and in vivo evaluation of novel implantation technology in hydrogel contact lenses for controlled drug delivery. J. Control. Release. 2016;226:47-56.

4. Verma M. S., Liu S., Chen Y. Y., Meerasa A., Gu F. X. Size-tunable nanoparticles composed of dextran-b-poly(d,I-lactide) for drug delivery applications. Nano Res. 2012;5:49-61.

5. Liechty W. B., Kryscio D. R., Slaughter B. V., Peppas N. A. Polymers for drug delivery systems. Annu. Rev. Chem. Bio-mol. Eng. 2010;1:149-173.
6. Weeks A., Subbaraman L. N., Jones L., Sheardown H. The competing effects of hyaluronic and methacrylic acid in model contact lenses. J. Biomater. Sci. Polym. Ed. 2012;23:1021-1038.

7. Paz E., Narbon J., Abenojar J., Del Real J. C., Cledera-Castro M. M. Influence of Acrylic Adhesive Viscosity and Surface Roughness on the Properties of Adhesive Joint. The Journal of Adhesion. 2015;92(11):877-891.

8. Knopf-Marques H., Pravda M., Wolfova L., Velebny V., Schaaf P., Vrana N. E., Lavalle P. Hyaluronic acid and its derivatives in coating and delivery systems: Applications in tissue engineering, regenerative medicine and immunomodulation. Adv. Healthc. Mater. 2016;5:2841-2855.

9. Hiratani H., Fujiwara A., Tamiya Y., Mizutani Y., Alvarez-Lorenzo C. Ocular release of timolol from molecularly imprinted soft contact lenses. Biomater. 2005;26:1293-1298.

10. Zhang V. V., Akhter K. F. Encapsulation and releasing of protein drugs through nano structured contact lens. ARVO. 2010;51(13):439.

11. Kim H. J., Zhang K., Moore L., Ho D. Diamond nanogel-embedded contact lenses mediate lysozyme-dependent therapeutic release. ACS Nano. 2014;8:2998-3005.

12. Bykovskiy S. N., Vasilenko I. A., Harchenko M. I. Handbook of instrumental research methods in the development and examination of the quality of drugs. Moscow: Pero. 2014. 656 p. (In Russ.).

13. Haywood A., Glass B. D. Pharmaceutical excipients - where do we begin? Australian Prescriber. 2011;34(4):112-114.

14. Zhilyakova E. T., Timoshenko E. Yu. Development of the composition and technology of eye drops based on miramistin. Vestn. new medical technologies. 2007;4(14):143-148.

15. Zhilyakova E. T., Novikov O. O., Novikova M. Yu., Popov N. N. The development of composition and technology of innovational combined medicinal preparation for treatment of infectious conjunctivitis bacterial etiology. Scientific sheets of BelSU. Medicine and Pharmacy. 2012;10(129):123-126. (In Russ.).

16. Alexeev K. V., Gritskova I. A., Kedik S. A. Polymers for pharmaceutical technology. Moscow: IFT. 2011. 512 p. (In Russ.). 